\title{
Pengetahuan Ibu Hamil tentang Gizi dengan Kejadian Anemia Selama Kehamilan
}

\author{
Yuniasih Purwaningrum ${ }^{1^{*}}$ \\ Prodi Kebidanan Jember, Indonesia \\ Email: yunipurwaningrum268@gmail.com*
}

\begin{abstract}
Abstrak
Kehamilan adalah suatu kondisi dimana wanita sedang mengandung janin di dalam rahimnya yang merupakan hasil dari sel sperma dengan sel ovum yang akan tumbuh dan berkembang menjadi bayi dan akan dilahirkan setelah usia kehamilan 40 minggu atau sekitar 9-10 bulan lamanya. Pengetahuan ibu hamil tentang gizi mempunyai peranan yang penting dalam pemenuhan gizi ibu. Pengetahuan ibu hamil tentang gizi di pengaruhi oleh beberapa faktor yaitu pengalaman, pendidikan dan umur. Kurangnya pengetahuan ibu hamil terhadap manfaat gizi dapat menyebabkan terjadinya anemia. Upaya yang dapat dilakukan untuk mencegah anemia pada ibu hamil dengan cara penyuluhan tentang gizi seimbang bagi ibu hamil dan pemberian tablet Fe. Di Puskesmas Sumberwringin tahun 2015 dari 361 ibu hamil 108 (30 \%) diantaranya mengalami anemia. Penelitian ini bertujuan untuk mengetahui hubungan pengetahuan ibu hamil tentang gizi dengan kejadian anemia pada ibu hamil. Penelitian ini menggunakan desain penelitian korelasi dengan pendekatan Cross Sectional. Populasinya adalah $57 \mathrm{ibu}$ hamil yang tercatat di register KIA Puskesmas Sumberwringin pada bulan Oktober sampai dengan Nopember 2016 dengan subjek sebanyak 32 ibu hamil dengan cara Random Sampling dengan menggunakan uji statistik Somers dengan tingkat signifikasi $\alpha \leq 0,05$. Hasil penelitian didapatkan pengetahuan ibu hamil tentang gizi yang berpengetahuan baik 8 (25\%), 1 ibu hamil dengan anemia dan 7 ibu hamil tidak anemia, cukup 13 (40\%), 3 ibu hamil anemia dan 10 ibu hamil tidak anemia, kurang 11 (34\%), 8 ibu hamil anemia dan 3 ibu hamil tidak anemia. Kemudian dilakukan uji Somers diperoleh hasil $\mathrm{p}=0,011$ lebih kecil dari $\alpha \leq 0,05$. Kesimpulan penelitian ini adalah ada hubungan antara pengetahuan ibu hamil tentang gizi dengan kejadian anemia selama kehamilan. Rekomendasi penelitian ini adalah pentingnya penyuluhan kepada ibu hamil tentang pemenuhan gizi selama masa kehamilan bagi ibu hamil dalam upaya mencegah terjadinya anemia pada masa kehamilan.
\end{abstract}

Kata Kunci: Pengetahuan, Ibu hamil, Gizi dan Anemia.

\section{Pendahuluan}

Kehamilan adalah suatu kondisi dimana wanita sedang mengandung janin di dalam akan dilahirkan setelah usia kehamilan 40 minggu atau sekitar 9-10 bulan lamanya (Sarwono, 1999). Ibu hamil mengalami perubahan fisiologi pada sistem reproduksi dan juga system organ (cardiovascular) sebagai adaptasi anatomi, fisiologi dan biokimia akibat respon terhadap stimulus fisiologis yang diberikan oleh janin atau jaringan janin (Manuaba, 1998).

Kehamilan membutuhkan gizi ibu lebih banyak. Gizi selama kehamilan sangat diperlukan untuk kesehatan ibu, kualitas kehamilan dan keselamatan bayi. Perbaikan keadaan gizi ibu selama kehamilan tidak hanya bermanfaat untuk ibu tersebut tetapi juga untuk mengoptimalkan pertumbuhan bayi didalam dan diluar kandungan. Ibu hamil memerlukan lebih banyak intake rahimnya yang merupakan hasil dari sel sperma dengan sel ovum yang akan tumbuh dan berkembang menjadi bayi dan protein, vitamin $\mathrm{C}$ dan zat besi dibanding wanita tidak hamil (Soetjiningsih, 1995).

Pengetahuan ibu hamil tentang gizimempunyai peranan yang penting dalam pemenuhan gizi ibu. Gizi ibu hamil yang baik diperlukan agar pertumbuhan janin berjalan pesat dan tidak mengalami hambatan (Soetjiningsih,1995). Kurangnya pengetahuan ibu hamil terhadap manfaat gizi selama kehamilan dapat menyebabkan ibu hamil kekurangan nutrisi. Ibu hamil bila mengalami kurang gizi terutama zat besi dan asam folat maka dapat terjadi anemia defisiensi zat besi.

Anemia pada kehamilan merupakan masalah nasional karena mencerminkan nilai kesejahteraan sosial ekonomi masyarakat dan pengaruhnya sangat besar terhadap kualitas sumberdaya manusia. Ibu hamil 
mengalami anemia bila kadar hemoglobin kurang dari $11 \mathrm{gr} / \mathrm{dl}$ atau kadar hematokritnya dibawah $37 \%$ pada trimester I, kadar hemoglobinn kurang dari 10,5 gr/dl atau kadar hematokritnya dibawah $35 \%$ pada trimestwer II dan kadar hemoglobin kurang dari $10 \mathrm{gr} / \mathrm{dl}$ atau kadar hematrokitnya dibawah $33 \%$ pada trimester III ( Bobak dkk, 2005 ).

Di Indonesia angka anemia dalam kehamilan menurut survey dr. Siswanto tahun 2002 masih tinggi yaitu $51 \%$ dari seluruh ibu hamil. Sedangkan menurut penelitian yang dilakukan Fakultas Kedokteran Udayana secara umum di Indonesia sekitar $50 \%$ wanita hamil menderita anemia.

Berdasarkan data Dinas Kesehatan Bondowoso selama tahun 2015 tercatat 914 atau $7,75 \%$ ibu hamil dengan anemia dari 11788 ibu hamil, di Puskesmas Sumberwringin tahun 2015 ibu hamil dengan anemia sebanyak $30 \%$ dari $361 \mathrm{ibu}$ hamil.

Berbagai penyulit dapat timbul akibat anemia diantaranya abortus, partus premature, partus lama akibat inertia uteri, perdarahan post partum akibat atonia uteri, syok, infeksi pada intra partum maupun post partum dan anemia berat. Pengaruh anemia terhadap hasil konsepsi diantaranya kematian mudigah, kematian perinatal, prematuritas, cacat bawaan dan cadangan besi kurang (Sarwono, 1999).

Defisiensi zat besi merupakan penyebab utama terjadinya anemia, yang paling lazim dan berkaitan dengan defisiensi asam folat terutama pada masa kehamilan. Banyak faktor yang menjadi penyebab terjadinya anemia zat besi antara lain kurangnya intake makanan, sosial ekonomi dan rendahnya pendidikan ibu (Manuaba, 1998).

Selama masa kehamilan sirkulasi darah ibu mengalami peningkatan. Volume darah meningkat dimana serum darah ibu lebih besar dari pertumbuhan sel darah sehingga terjadi pengenceran darah (hemodilusi) dan curah jantung akan bertambah sekitar $30 \%$. Sedangkan sel darah merah semakin meningkat jumlahnya untuk dapat mengimbangi pertumbuhan janin dalam rahim, tetapi pertambahan sel darah tidak seimbang dengan peningkatan volume darah sehingga terjadi hemodilus yang disertai anemia fisiologis (Manuaba, 1998).

Berdasarkan uraian diatas dapat diketahuai bahwa pentingnya penyuluhan ante natal care pada ibu hamil sehingga pengetahuan ibu hamil terhadap gizi selama kehamilan meningkat. Kekurangan gizi selama kehamilan dapat mengakibatkan ibu hamil kurang gizi, sehingga berdampak dengan masih tingginya kasus anemia pada ibu hamil, khususnya di Puskesmas Sumberwringin Kabupaten Bondowoso. Kurangnya pengetahuan dan rendahnya pendidikan ibu hamil serta kurangnya informasi pada ibu hamil tentang manfaat gizi selama kehamilan semakin memperburuk kondisi ibu hamil.

\section{Metode penelitian}

Desain penelitian ini adalah desain penelitian korelasi dengan pendekatan cross sectional dimana peneliti melakukan observasi satu kali saja dan pengukuran variable dependent dan independent pada saat pemeriksaan atau pengkajian data. Populasi pada penelitian ini adalah ibu hamil yang ada di Puskesmas Sumberwringin Kabupaten Bondowoso tahun 2016 sebanyak 57 ibu hamil dan berdasarkan rumus diambil subjek sebanyak $32 \mathrm{ibu}$ hamil.

Teknik sampling pada penelitian ini menggunakan random sampling yaitu dengan mengambil subjek secara acak.

Hasil perolehan data dimasukkan pada lembar tabulasi data dan dianalisa dengan uji stastistik Somers.

\section{Hasil dan pembahasan}

\subsection{Hasil Penelitian}

Hasil penelitian ini terdiri dari data umum dan data khusus. Data umum meliputi usia ibu hamil, pendidikan, pekerjaan dan penghasilan ibu hamil. Sedangkan data khusus meliputi umur kehamilan, pengetahuan ibu hamil tentang gizi selama kehamilan, kejadian anemia pada ibu hamil dan hubungan pengetahuan ibu hamil tentang gizidengan kejadian anemia selama kehamilan. 
Tabel 1. Distribusi umur ibu hamil di Puskesmas Sumberwringin Bondowoso bulan Oktober Nopember tahun 2016

\begin{tabular}{ccc}
\hline Umur & Jumlah & Persentase \\
\hline$\leq 17$ tahun & 4 & 12,5 \\
$18-34$ tahun & 18 & 56,3 \\
$\geq 35$ tahun & 10 & 31,2 \\
\hline Jumlah & 32 & 100 \\
\hline
\end{tabular}

Berdasarkan tabel 1diketahui bahwa ibu hamil usianya kurang dari 17 tahun 4 $(12,5 \%)$, ibu hamil berusia 18 - 34 tahun sebanyak $18(56,3 \%)$ dan $10(31,2 \%)$ ibu hamil berusia diatas 35 tahun.

Tabel 2. Distribusi pendidikan ibu hamil di Puskesmas Sumberwringin Bondowoso bulan Oktober Nopember tahun 2016

\begin{tabular}{lcc}
\hline \multicolumn{1}{c}{ Pendidikan } & Jumlah & Persentase \\
\hline SD - SMP & 27 & 85 \\
SLTA & 3 & 10 \\
Perguruan Tinggi & 2 & 5 \\
\hline \multicolumn{1}{c}{ Jumlah } & 32 & 100 \\
\hline
\end{tabular}

Dari tabel 2. dapat dilihat bahwa tingkat pendidikan ibu hamil paling banyak adalah SD - SMP sebanyak 27 (85 \%) ibu hamil, berpendidikan SLTA 3 (10\%) ibu hamil dan hanya $2(5 \%)$ ibu hamil yang berpendidikan Perguruan Tinggi.

Tabel 3. Distribusi Pekerjaan Ibu Hamil Di Puskesmas Sumberwringin Bondowoso Bulan Oktober Nopember Tahun 2016

\begin{tabular}{lcc}
\hline \multicolumn{1}{c}{ Pekerjaan } & Jumlah & Persentase \\
\hline Swasta & 14 & 43,7 \\
PNS & 3 & 9,4 \\
Ibu Rumah Tangga & 15 & 46,9 \\
\hline \multicolumn{1}{c}{ Jumlah } & 32 & 100 \\
\hline
\end{tabular}

Dari tabel 3. diatas dapat diketahui bahwa pekerjaan ibu hamil adalah swasta 14 (43,7 $\%$ ) dan hanya 3 (9,4 \%), Pegawai Negeri Sipil $3(9,4 \%)$ dan ibu rumah tangga sebanyak $15(46,9 \%)$.

Tabel 4. Distribusi penghasilan ibu hamil di Puskesmas Sumberwringin Bondowoso bulan OktoberNopember tahun 2016

\begin{tabular}{lcc}
\hline \multicolumn{1}{c}{ Penghasilan } & Jumlah & Persentase \\
\hline$\leq$ Rp. 500. 000,- & 17 & 53,1 \\
Rp. 500.000,- s/d & 9 & 28 \\
Rp. 1.000.000,- & & \\
$\geq$ Rp. 1.000.000,- & 6 & 18,9 \\
\hline \multicolumn{1}{c}{ Jumlah } & 32 & 100 \\
\hline
\end{tabular}

Dari tabel 4. dapat diketahui bahwa sebagian besar ibu hamil berpenghasilan dibawah $\mathrm{Rp}$. 500.000 ,- yaitu sebanyak $17(53,1 \%)$ ibu hamil, $9(28 \%)$ berpenghasilan lima ratus ribu sampai dengan satu juta dan hanya 6 $(18,9 \%)$ yang berpenghasilan diatas 1 juta.

Tabel 5. Distribusi Umur Kehamilan ibu hamil di Puskesmas Sumberwringin Bondowoso bulan Oktober - Nopember tahun 2016

\begin{tabular}{ccc}
\hline $\begin{array}{c}\text { Usia } \\
\text { Kehamilan }\end{array}$ & Jumlah & Persentase \\
\hline Trimestrer I & 8 & 25 \\
Trimestrer II & 15 & 46,9 \\
Trimestrer III & 9 & 28,1 \\
\hline \multicolumn{1}{c}{ Jumlah } & 32 & 100 \\
\hline
\end{tabular}

Dari tabel 5. diatas dapat diketahui bahwa 8 (25\%) usia kehamilan ibu hamil pada trimester pertama, $15 \quad(46,9 \%)$ usia kehamilan ibu hamil adalah pada trimester kedua dan $9(28,1 \%)$ usia kehamilan ibu hamil pada trimester ketiga.

Tabel 6. Distribusi Pengetahuan Ibu Hamil Tentang Gizidi Puskesmas Sumberwringin Bondowoso Bulan OktoberNopember tahun 2016

\begin{tabular}{|c|c|c|}
\hline $\begin{array}{c}\text { Tingkat } \\
\text { Pengetahuan }\end{array}$ & Jumlah & Persentase \\
\hline Baik & 8 & 25 \\
\hline Cukup & 13 & 40 \\
\hline Kurang & 11 & 34 \\
\hline Jumlah & 32 & 100 \\
\hline
\end{tabular}

Dari tabel 6. menunjukan bahwa $8(25 \%)$ ibu hamil mempunyai pengetahuan baik, 13 (40 \%) ibu hamil mempunyai pengetahuan cukup dan 11 (34\%) ibu hamil mempunyai pengetahuan kurang. 
Tabel 7. Distribusi Kejadian Anemia pada Ibu Hamil di Puskesmas Sumberwringin Bondowoso Bulan Oktober - Nopember Tahun 2016

\begin{tabular}{lcc}
\hline \multicolumn{1}{c}{$\begin{array}{c}\text { Kejadian } \\
\text { Anemia }\end{array}$} & Jumlah & Persentase \\
\hline $\begin{array}{l}\text { Tidak Anemia } \\
\text { Anemia }\end{array}$ & 20 & 64 \\
& 12 & 36 \\
\hline \multicolumn{1}{c}{ Jumlah } & 32 & 100 \\
\hline
\end{tabular}

Dari tabel 7. menunjukkan 20 (64\%) ibu hamil tidak mengalami anemia dalam kehamilan, dan 12 (36 \%) ibu hamil mengalami anemia dalam kehamilan.

Tabel 8. Hubungan Pengetahuan Ibu Hamil tentang Gizi dengan Kejadian Anemia Selama Kehamilan di Puskesmas Sumberwringin Bondowoso Bulan Oktober - Nopember Tahun 2016

\begin{tabular}{cccc}
\hline $\begin{array}{c}\text { Tingkat } \\
\text { Pengetahu- } \\
\text { an }\end{array}$ & \multicolumn{2}{c}{ Kejadian Anemia } & Jumlah \\
\cline { 2 - 3 } & Anemia & $\begin{array}{c}\text { Tidak } \\
\text { Anemia }\end{array}$ & \\
\hline Baik & 1 & 7 & 8 \\
& $(3,125$ & $(21,875$ & $(25 \%)$ \\
& $\%)$ & $\%)$ & \\
\hline Cukup & 3 & 10 & 13 \\
& $(9,375$ & $(31,25$ & $(40,625$ \\
& $\%)$ & $\%)$ & $\%)$ \\
\hline Kurang & 8 & 3 & 11 \\
& $(25 \%)$ & $(9,375$ & $(34,375$ \\
& & $\%)$ & $\%)$ \\
\hline Jumlah & 12 & 20 & 32 \\
& $(37,5 \%)$ & $(62,5 \%)$ & $(100$ \\
& & & $\%)$ \\
\hline
\end{tabular}

Dari tabel 8. hubungan antara variabel independent pengetahuan ibu hamil tentang gizi dengan variabel dependent kejadian anemia selama masa kehamilan dilakukan uji statistik dengan menggunakan uji ChiSquare dengan SPSS, tetapi karena kurang memenuhi syarat kemudian diganti dengan menggunakan uji Somers diperoleh nilai $\mathrm{p}=$
0,011 dimana lebih kecil dari $\alpha \leq 0,05$ yang berarti ada hubungan antara pengetahuan ibu hamil tentang gizi dengan kejadian anemia pada ibu hamil.

\subsection{Pembahasan}

\section{a. Identifikasi pengetahuan ibu hamil tentang gizi}

Pengetahuan ibu hamil tentang gizi selama kehamilan sebagian besar adalah cukup yaitu $13(40 \%)$ ibu hamil dan 8 (25 $\%)$ ibu hamil berpengetahuan baik. Hal ini disebabkan ibu mempunyai pengetahuan cukup dan baik yang diperolehnya dari pendidikan formal maupun informal dan seringnya dilakukan promosi kesehatan tentang pentingnya makanan bergizi bagi ibu hamil selama kehamilan baik secara langsung oleh petugas kesehatan ataupun media massa baik cetak (majalah, koran) dan elektrolik (televisi, radio), dimana pengetahuan dan informasi dapat dengan mudah diperoleh. Ibu hamil yang mempunyai pengetahuan kurang $11(35 \%)$ ibu hamil, hal ini disebabkan kebanyakan ibu hamil berpendidikan rendah, dimana pendidikan ibu hamil sebagian besar hanya SD sampai SLTP yaitu sebanyak 27 (85\%) ibu hamil, pengalaman ibu hamil tentang kehamilan kurang dan juga pekerjaan dimana sebagian besar ibu hamil berprofesi sebagai ibu rumah tangga.

Pendidikan ibu hamil yang sebagian besar hanya SD sampai SLTP, hal ini mengakibatkan penerimaan ibu hamil terhadap informasi terbatas pada tingkat tahu saja tentang gizi, sedangkan untuk menerapkannya dalam kehidupan sehari hari terutama saat hamil masih kurang, oleh karena tingkat pemahaman ibu hamil rendah. Sehingga semakin tinggi pendidikan seseorang maka semakin tinggi pula tingkat pengetahuannya.

Menurut Notoatmadjo (2007) bahwa pengetahuan diperoleh melalui mata dan telinga dan juga dipengaruhi oleh pendidikan, pengalaman dan usia. Dimana semakin tinggi pendidikan seseorang semakin mudah menerima informasi sehingga semakin banyak pula pengetahuan yang dimilikinya. Sebaliknya pendidikan yang kurang akan menghambat perkembangan pengetahuan seseorang 
terhadap nilai-nilai baru yang diperkenalkan.

\section{b. Identifikasi kejadian anemia dalam kehamilan}

Dari hasil penelitian didapatkan sebanyak $12(36 \%)$ ibu hamil mengalami anemia dalam kehamilannya. Hal ini disebabkan selama kehamilannya ibu hamil banyak berpantangan terhadap makanan tertentu, kurangnya pengetahuan ibu tentang pentingnya gizi selama kehamilan dan cara menyediakan makanan yang tidak benar dapat merusak jenis vitamin yang terkandung didalamnya. Apabila makanan yang dikonsumsi setiap hari tidak cukup banyak zat besi atau absorbsinya rendah maka ketersediaan zat besi untuk tubuh tidak cukup memenuhi kebutuhan akan zat besi. Hal ini terutama terjadi pada orang-orang yang mengkonsumsi makanan kurang beragam seperti menu makanan yang hanya terdiri dari nasi dan sayuran saja. Mual muntah yang berlebihan pada ibu hamil juga dapat menyebabkan kekurangan zat makanan sehingga berpengaruh pada ibu dan janin. Demikian pula pada keadaan sosial ekonomi ibu yang rendah dapat menyebabkan rendahnya kemampuan keluarga dalam menyediakan makanan yang cukup mengandung gizi yang diperlukan bagi ibu hamil.

Menurut Soetjiningsih (1995) pengetahuan ibu hamil tentang gizi mempunyai peranan yang penting dalam pemenuhan gizi ibu, dimana gizi yang baik diperlukan agar pertumbuhan janin berjalan pesat dan tidak mengalami hambatan. Kurangnya pengetahuan ibu hamil terhadap manfaat gizi selama kehamilan dapat menyebabkan ibu hamil kekurangan gizi dan dapat berakibat terjadinya anemia.

Menurut Sarwono (1999) anemia lebih sering ditemukan pada masa kehamilan. Hal ini disebabkan karena dalam kehamilan kebutuhan akan zat - zat makanan bertambah dan terjadi pula perubahan perubahan dalam darah dan sumsum tulang. Faktor utama yang menjadi penyebab terjadinya anemia adalah kurangnya konsumsi zat besi yang ada dalam makanan. Pada ibu hamil pada trimester pertama sering merasa mual dan muntah, biasanya terjadi pada pagi hari tetapi dapat pula timbul setiap saat dan malam.

Hal lain yang menjadi penyebab terjadinya anemia adalah pada golongan masyarakat yang berpenghasilan rendah, mereka pada umumnya mengkunsumsi jenis makanan yang kurang beragam dan memiliki kandungan zat besi yang rendah, sehingga kebutuhan zat besi menjadi tidak optimal.

Menurut Bobak dkk (2005) gizi merupakan satu dari banyak faktor yang ikut mempengaruhi hasil akhir kehamilan. Status gizi dipengaruhi oleh banyak faktor seperti kemiskinan, kurang pendidikan, lingkungan yang buruk, kebiasaan makan yang aneh dan kondisi kesehatan yang buruk. Adapun menurut Pudjiadi (2001) gizi bagi ibu hamil harus lebih beragam dan cukup mengandung seng, magnesium, kalsium dan vitamin untuk kebutuhan ibu dan perkembangan janin.

Ibu hamil yang mengalami anemia pada masa kehamilan sangat beresiko bagi ibu, baik itu pada saat kehamilan, persalinan dan juga masa nifas, dan juga dapat mengganggu perkembangan dan pertumbuhan janin. Pencegahan anemia pada ibu hamil sangat penting, untuk itu ibu hamil harus mampu memenuhi kebutuhan gizi yang diperlukan bagi perkembangan tubuh dan juga janinnya, sehingga bagi ibu hamil dianjurkan untuk makan secukupnya, bahan tidak perlu mahal tetapi cukup mengandung vitamin dan bergizi.

Menurut Sarwono (1999) kekurangan dan kelebihan gizi dapat menyebabkan kelainan pada ibu hamil. Kekurangan makanan dapat menyebabkan anemia, abortus, partus prematur, inertia uteri, hemorargi post partum dan sepsis purpuralis. Sedangkan makanan secara berlebihan dapat menyebabkan komplikasi antara lain pre eklamsi dan janin besar. Menurut Mochtar (1998) gizi juga diperlukan untuk pertumbuhan janin dan plasenta, uterus, payudara dan kenaikan metabolisme, dimana pada masa kehamilan ibu juga mengalami kenaikan berat badan. 


\section{c. Hubungan antara pengetahuan dengan kejadian anemia selama kehamilan}

Dari uji Somers diperoleh hasil nilai $\mathrm{p}$ $=0,011$ dimana lebih kecil dari $\alpha \leq 0,05$. Berdasarkan analisis data diatas maka ada hubungan bermakna antara pengetahuan ibu hamil tentang gizi dengan kejadian anemia di Puskesmas Sumberwringin Kabupaten Bondowoso, yang artinya hipotesa diterima.

Dari tabel 7. dapat diketahuai bahwa dari 32 ibu hamil menunjukkan jumlah ibu hamil yang mengalami anemia dalam kehamilannya sebanyak 12 (36 \%) ibu hamil dari total semua ibu hamil. Hal ini berarti tingkat anemia di Puskesmas Sumberwringin melebihi prevalensi anemia di Kabupaten Bondowoso yang hanya 7,75\%.

Dari tabel 6. sebagian besar ibu hamil mempunyai pengetahuan cukup $13(40 \%)$ dan baik 8 (25\%), dimana dari jumlah ibu hamil yang mempunyai pengetahuan baik hanya $1(3,125 \%)$ yang mengalami anemia dan ibu hamil yang berpengetahuan cukup hanya $3(9,375 \%)$ yang menderita anemia. Hal ini disebabkan pengetahuan ibu tentang gizi selama kehamilannya sangat beragam. Informasi tentang pentingnya gizi selama kehamilan sudah banyak didapatkan melalui penyuluhan, pengalaman dan media cetak (koran, majalah, pamflet) dan juga media elektronik (televisi, radio).

Hasil lain yang didapat adalah pengetahuan yang kurang yaitu sebanyak 11 (35\%) ibu hamil. Hal ini disebabkan ibu hamil tersebut rata - rata berpendidikan hanya SD sampai SLTP. Faktor-faktor penghambat dalam upaya penurunan kejadian anemia antara lain : keterbatasan dana, jalur distribusi, mutu pelayanan, Komunikasi-Informasi-Edukasi (KIE) dan kepatuhan. Hal mendasar yang mempengaruhi timbulnya anemia adalah rendahnya pendidikan, rendahnya kemampuan daya beli, status sosial yang rendah dan lokasi geografis.

Pengetahuan ibu hamil tentang pentingnya gizi selama kehamilannya merupakan faktor yang menyebabkan perilaku ibu hamil dalam menerapkan makanan yang bergizi selama kehamilannya. Oleh karena itu seseorang dengan pengetahuan rendah akan sulit berespon atau mencoba sesuatu yang baru karena dibayangi rasa takut salah dan pengetahuan yang rendah juga merupakan faktor penghambat untuk menerima suatu motivasi termasuk dalam bidang kesehatan.

Hal ini relevan dengan Notoatmodjo (2007) bahwa pengetahuan dipengaruhi oleh pendidikan. Pendidikan yang tinggi membuat seseorang semakin mudah menerima informasi, sehingga semakin banyak pula pengetahuan yang dimiliki, sebaliknya pendidikan yang rendah akan menghambat perkembangan seseorang dalam menerima hal yang baru.

\section{Kesimpulan}

Ada hubungan antara pengetahuan ibu hamil tentang gizi dengan kejadian anemia selama kehamilan dengan uji Somers diperoleh nilai $\mathrm{p}=0,011$ lebih kecil dari $\alpha \leq$ 0,05 . Sehingga dapat diambil kesimpulan kurangnya pengetahuan ibu hamil tentang gizi dapat menyebabkan anemia pada masa kehamilan.

\section{Daftar pustaka}

Bobak, Lowdermilk, Jensen, (2005). Keperawatan Maternitas Edisi 4, Jakarta.

Manuaba, I.B., (1998). Ilmu Kebidanan, Penyakit Kandungan \& Keluarga Berencana untuk Pendidikan Bidan, Jakarta, EGC.

Mochtar, R., (1998). Siniopsis Obstetri, Jakarta, EGC..

Notoatmojdo, S.,(2007). Promosi Kesehatan \& Ilmu Perilaku, Jakarta.

Pudjiadi, S., (2001). Ilmu Gizi Klinis pada Anak, Jakarta

Sarwono Prawirohardjo, (1999). Ilmu Kandungan, Jakarta, Fakultas Kedokteran Universitas Indonesia

Soetjiningsih, (1995). Tumbuh Kembang Anak, Jakarta, EGC. 